\title{
Keefektifan Penerapan Model Talking Stick Terhadap Hasil Belajar Tema Cita-Citaku
}

\author{
Risma Rossyana Wijayanto* \\ Jurusan Pendidikan Guru Sekolah Dasar, Universitas PGRI Semarang Semarang, Indonesia
}

\author{
A R T I C L E I N F O \\ Article history: \\ Received 10 February \\ 2019 \\ Received in revised form \\ 09 March 2019 \\ Accepted 15 April 2019 \\ Available online 25 May \\ 2019 \\ Kata Kunci: \\ Talking Stick, Hasil Belajar \\ Keywords: \\ Talking Stick, learning \\ outcomes.
}

\begin{abstract}
A B S T R A K
Penelitian ini bertujuan untuk mendeskripsikan seberapa besar keefektifan penerapan model Talking Stick terhadap hasil belajar peserta didik dalam tema cita-citaku siswa kelas IV SD N 1 Sukodadi. Metode penelitian ini yang digunakan adalah metode eksperimen semu dengan rancangan penelitian yang digunakan adalah pre experimental design. Sampel dalam penelitian ini adalah 32 peserta didik. Hasil analisis data menunjukkan bahwa hasil belajar peserta didik pada postest di kelas eksperimen efektif digunakan sebesar 0,14 . Hal ini berarti pembelajaran dengan menerapkan model Talking Stick efektif dengan kriteria tinggi terhadap hasil beljar peserta didik kelas IV dalam pembelajaran tema cita-citaku di SD N 1 Sukodadi.
\end{abstract}

\section{A B S T R A C T}

This study aims to describe the effectiveness of the Talking Stick model to the learning outcomes of students in the theme of the ideals of my fourth grade students at SD N 1 Sukodadi. This research method used is a quasi- experimental method with the research design used was pre experimental design. The sample in this study were 32 students. The results of data analysis showed that the learning outcomes of students in the posttest in the experimental class were effectively used at 0,14. This mean learning by applying an effective Talking Stick model with high criteria towards learning outcomes of class IV students in learning the theme of my ideals at SD N 1 Sukodadi.

\section{Pendahuluan}

Pendidikan adalah pengaruh lingkungan atas individu untuk menghasilkan perubahan-perubahan yang tetap (permanen) didalam kebiasaan-kebiasaan tingkah lakunya, pikiranya, dan sikapnya. Menurut (Hakim, dkk, 2018) Pendidikan Sekolah Dasar merupakan pondasi awal dalam pengenalan pada anak untuk kehidupan dimasyarakat dan untuk jenjang pendidikan lebih tinggi. Pendidikan merupakan usaha manusia untuk menyiapkan diri dalam peranannya dimasa yang akan datang. Oleh karena itulah keterampilan yang berkaitan dengan pemahaman konsep menjadi sangat penting sebagai bekal bagi peserta didik untuk mereka dapat hidup mandiri di lingkungan masyarakat serta membantu mereka dalam menyelesaikan masalah yang berkaitan dengan kehidupan sehari-hari.

Undang-undang No. 20 Tahun 2003 Tentang Sistem Pendidikan Nasional menyatakan bahwa, pendidikan adalah usaha sadar dan terencana untuk mewujudkan suasana belajar dan proses pembelajaran agar peserta didik secara aktif mengembangkan potensi dirinya untuk memiliki kekuatan spiritual keagamaan, pengendalian diri, kepribadian, kecerdasan, akhlak mulia, serta keterampilan yang diperlukan dirinya, masyarakat, bangsa dan Negara. Dalam hal ini proses pembelajaran di dalam kelas harus memperhatikan komponen-komponen belajar mengajarnya. Menurut Djamarah dan (Djamarah, dkk, 2010:41), komponen-komponen belajar mengajar meliputi tujuan, bahan pelajaran, kegiatan belajar mengajar, metode, model, alat dan sumber serta evaluasi.

Copyright (c) Universitas Pendidikan Ganesha. All rights reserved. 
Bukan pada guru saja, pada pembelajaran ada banyak faktor yang mempengaruhi tercapainya tujuan pembelajaran diantaranya guru, siswa lingkungan, metode/strategi, dan media pembelajaran. Media pembelajaran sangat berpengaruh bagi anak-anak dalam proses belajar. Media pembelajaran digunakan untuk menyampaikan pesan atau informasi dari materi pelajaran tersebut. Menurut Gagne (1970) dalam (Sadiman, dkk, 2012: 6), media adalah berbagai jenis komponen dalam lingkungan siswa yang dapat merangsang siswa untuk belajar. Sementara menurut briggs (1970) dalam (Sadiman, dkk, 2012: 6) menyatakan bahwa media adalah segala alat fisik yang dapat menyajikan pesan serta merangsang siswa untuk belajar. Film, kaset, dan gambar adalah contoh-contohnya.

Sedangkan belajar adalah suatu proses usaha yang dilakukan seseorang untuk memperoleh perubahan tingkah laku yang baru secara keseluruhan, sebagai hasil pengalamannya sendiri dalam interaksi dengan lingungannya (Slameto, 2003: 2). Perubahan itu bersifat relative konstan dan berbekas. Dalam kaitan ini, proses belajar dan perubahan merupakan bukti hasil yang diproses yang meliputi kognitif, afektif, dan spikomotorik. Belajar tidak hanya mempelajari mata pelajaran, tetapi juga penyusunan, kebiasaan, persepsi, kesenangan atau minat, penyesuaian sosial, bermacam-macam keterampilan lain, dan cita-cita ((Hamalik, 2006:45). Dengan demikian, seseorang dikatakan belajar apabila terjadi perubahan pada dirinya akibat adanya latihan dan pengalaman melalui interaksi dengan lingkungan. Menurut secara spikologis, belajar merupakan suatu proses perubahan, yaitu perubahan tingkah laku sebagai hasil interaksi dengan lingkungannya dalam memenuhi kebutuhan hidupnya ((Slameto, 2003: 2).

Pembelajaran tematik adalah pembelajaran yang dirancang menggunakan tema sebagai pemersatu materi dalam beberapa mata pelajaran sekaligus dalam satu kali pertemuan. Dalam pembelajaran tema diberikan kepada siswa dengan maksud menyatukan kurikulum dalam satu kesatuan yang utuh (Majid, 2014: 85-87).

Proses pembelajaran yang berlangsung umumnya masih menggunakan metode ceramah, dimana guru menerangkan materi dan siswa hanya mendengarkan serta mencatat saja, sehingga keaktifan dalam pembelajaran tidak ada. Penggunaan metode dan model pembelajaran oleh seorang guru sangat berpengaruh dalam keaktifan belajar siswa. Seorang guru dapat menggunakan berbagai model atau metode mengajar untuk mencapai tujuan pengajaran, dimana metode atau model pembelajaran yang dipakai dapat menarik perhatian siswa sehingga dapat meningkatkan keaktifan dan hasil belajar siswa dalam proses pembelajaran.

Selain itu, apabila proses pembelajaran yang diterapkan oleh guru masih kurang menarik, maka mengakibatkan siswa tidak terlibat sama sekali saat proses belajar mengajar berlangsung. Akibatnya, banyak siswa yang terlihat malas saat pembelajaran tersebut,sehingga saat adanya evaluasi, siswa kurang percaya diri dalam mengerjakan soal-soal evaluasi dan hasil belajar kurang memuaskan.

Adapun Soekamto (dalam Trianto, 2011: 142) mengemukakan maksud dari model pembelajaran adalah kerangka konseptual yang melukiskan prosedur yang sistematis dalam mengorganisasikan pengalaman belajar untuk mencapai tujuan belajar tertentu, dan berfungsi sebagai pedoman bagi para perancang pembelajatran dan para pengajar dalam merencanakan aktivitas belajar mengajar. Hal ini berarti model pembelajaran memberikan kerangka dan arah bagi guru untuk mengajar.

Fungsi model pembelajaran adalah sebagai pedoman bagi pengajar dan para guru dalam meaksanakan pembelajaran. Hal ini menunjukaan bahwa setiap model yang akan digunakan dalam pembelajaran menentukan perangkat yang dipakai dalam pembelajaran tersebut.

Menurut (Safitri, dkk, 2018) model pembelajaran Talking Stick melatih peserta didik untuk mampu menguji kesiapan peserta didik, melatih keterampilan peserta didik dalam membaca dan memahami materi pelajaran dengan cepat dan mengajak mereka untuk terus siap dalam situasi apapun, pembelajaran Talking Stick sangat cocok diterapkan bagi peserta didik, selain untuk melatih berbicara, pembelajaran ini akan menciptakan suasana yang menyenangkan dan membuat peserta didik aktif. Menurut (Siregar, 2015) Talking Stick (tongkat berbicara) adalah metode pembelajaran Talking Stick dilakukan dengan bantuan tongkat, siapa yang memegang tongkat wajib menjawab pertanyaan dari guru setelah siswa mempelajari materi pokoknya. Selain untuk melatih berbicara, model ini juga menuntut siswa dapat bekerjasama dengan teman-temannya agar dapat mengerti dan siap untuk menjawab pertanyaan dari guru. Menurut (Sohimin, 2014:197) Talking Stick (tongkat berbicara) adalah metode yang pada mulanya digunakan oleh penduduk asli amerika untuk mengajak semua orang berbicara atau menyampaikan pendapat dalam suatu forum (pertemanan antar suku). Talking Stick (tongkat berbicara) telah dipergunakan selama berabad-abad oleh suku-suku Indian sebagai alat menyimak secara adil dan tidak memihak. Tongkat berbicara sering digunakan kalangan dewan untuk memutuskan siapa yang mempunyai hak berbicara. Pada saat pimpinan rapat mulai berdiskusi dan membahas masalah, ia harus memegang tongkat. Tongkat akan pindah ke orang lain apabila ingin mengemukakan pendapatnya. Apabila semua mendapatkan giliran berbicara, tongkat itu lalu dikembalikan lagi ke ketua/pimpinan 
rapat. Dari penjelasan di atas dapat disimpulkan bahwa Talking Stick dipakai sebagai tanda seseorang mempunyai hak suara (berbicara) yang diberikan secara bergiliran/bergantian. Menurut Wulandari (2015) pembelajaran dengan metode Talking Stick diawali dengan penjelasan guru mengenai materi pokok yang akan dipelajari. Siswa diberi kesempatan membaca dan mempelajari materi tersebut. Guru selanjutnya meminta siswa menutup bukunya. Kemudian Guru mengambil tongkat. Tongkat tersebut digulirkan kepada siswa sekitar 15 detik. Siswa yang mendapatkan tongkat tersebut diwajibkan menjawab pertanyaan dari guru. Menurut (Faradita, 2018) terdapat beberapa kelebihan dan kelemahan dalam model pembelajaran type Talking Stick. Kelebihan model Talking Stick yaitu menguji kesiapan siswa, melatih siswa memahami materi dengan cepat agar siswa lebih giat belajar (belajar dahulu sebelum pelajaran dimulai). Sedangkan kelemahan model pembelajaran ini adalah membuat siswa tegang karena takut mendapatkan pertanyaan yang harus dijawab.

Model pembelajaran Talking Stick termasuk salah satu model pembelajarn kooperatif. Strategi pembelajaran ini dilakukan dengan bantuan tongkat, siapa yang memegang tongkat wajib menjawab pertanyaan dari guru setelah peserta didik mempelajari materi pokoknya. Pembelajaran Talking Stick sangat cocok diterapkan bagi peserta didik SD, SMP, dan SMA/SMK. Selain untuk melatih berbicara, pembelajaran ini akan menciptakan suasana yang menyenangkan dan membuat peserta didik aktif.

Pembelajaran dengan strategi Talking Stick mendorong peserta didik untuk berani mengemukakan pendapat. Strategi ini diawali dengan penjeasan guru mengenai materi pokok yang akan dipelajari. Kemudian dengan bantuan tongkat (stick) yang bergulir peserta didik dituntun untuk merefleksi atau mengulang kembali materi yang sudah dipelajari dengan cara menjawab pertanyaan dari guru. Siapa yang memegang tongkat, dialah yang wajib menjawab pertanyaan (talking).

Penelitian ini terdiri dari variabel bebas dan terikat yang saling berhubungan. Variabel bebas dalam penelitian ini adalah model Talking Stick, sedangkan variabel terikat penelitian adalah hasil belajar tema Cita-citaku kelas IV. Proses pembelajaran yang berlangsung di kelas sering menggunakan pembelajaran yang berpusat pada guru. Dalam proses pembelajaran peran guru lebih dominan dan peran siswa kurang, karena hal tersebut menjadi tidak aktif serta menjadi cepat hilang fokus karena siswa tidak ikut serta dan pembelajaran hanya didominasi guru. Akibat kehilangan fokus, kemampuan siswa menerima informasi yang yang disampaikan guru menjadi terhambat karena tidak terfokus pada materi. Hal tersebut juga membuat siswa menjadi sulit mengingat materi yang disampaikan oleh guru.

\section{Metode}

Metode penelitian ini menggunakan penelitian kuantitatif yang bertujuan untuk mengetahui efektifitas suatu perlakuan terhadap sampe.Perlakuan yang dimaksud adalah penggunakan model pembelajaran Talking Stick di SD N 1 Sukodadi sebagai kelas penelitian. Metode ini menggunakan pre experimental design one group pretest-posttest design dengan subjek penelitian hanya menggunakan satu kelas experiment. Peneliti membandingkan nilai pretest dan posttest peserta didik sebelum dan sesudah diberi perlakuan dalam kegiatan pembelajaran dengan menggunakan talking stick.

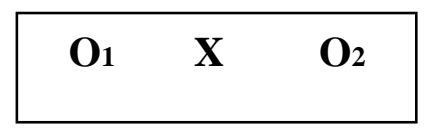

Gambar 1. Desain Penelitian Pre Experimental Design

$\begin{array}{ll}\text { Keterangan } \\ \mathrm{O}_{1} & \text { :Tes awal sebelum adanya perlakuan } \\ \mathrm{O}_{2} & \text { : Tes akhir sesudah adanya perlakuan } \\ \mathrm{X} & \text { : Perlakuan dengan Group Investigation }\end{array}$

Dalam penelitian ini, kelas diberi pretest untuk mengetahui kondisi awal kemampuan hasil belajar sebelum adanya perlakuan, kemudian kelas diberi perlakuan dengan talking stick. Selanjutnya diberi posttest sesudah diberi perlakuan untuk mengetahui ada tidaknya perubahan terhadap hasil belajar siswa. Berikut tabel rancangan desain penelitian. 
Tabel 1. Rancangan desain One Group Pretest-posttest Design

\begin{tabular}{|c|c|c|c|c|c|}
\hline Kelompok & Tes & Perlakuan & & & Tes \\
\hline Kelas IV & ${ }_{\text {etest }}{ }^{P r}$ & $\begin{array}{l}\text { Pembelajaran } \\
\text { Investigation }\end{array}$ & Model & Grup & Posttest \\
\hline
\end{tabular}

Populasi adalah wilayah generasi yang terdiri ats obyek/subjek yang mempunyai kualitas dan karakteristik tertentu yang ditetapkan oleh peneliti untuk dipelajari dan kemudian ditarik kesimpulannya (Sugiyono, 2016:117). Seluruh siswa kelas IV SDN 1 Sukodadi Kendal merupakan populasi dalam penelitian ini. Data yang diungkap dalam penelitian ini dibedakan menjadi tiga jenis, yaitu : fakta, pendapat, dan kemampuan.

a) Tes

Untuk mengukur ada atau tidaknya serta besarnya kemampuan objek yang diteliti menggunakan tes (Arikunto, 2016 :266). Dalam penelitian ini tes yang digunakan tes tertulis berupa soal pilihan ganda yang dilakukan dengan pretest dan posttest. Pretest digunakan untuk mengetahui tingkat kemampuan awal siswa, sedangkan posttest digunakan untuk mengetahui berhasil atau tidaknya proses pembelajaran pada tema cita-citaku siswa kelas IV dengan menggunakan model Talking Stick di SDN 1 Sukodadi Kecamatan Kangkung Kabupaten Kendal.

b) Wawancara

Wawancara merupakan salah satu bentuk teknik pengumpulan data yang banyak digunakan dalam penelitian deskriptif kualitatif dan deskriptif kuantitatif. Wawancara dilaksanakan secara lisan dalam pertemuan tatap muka secara individual. Wawancara dilakukan untuk mengetahui secara langsung dari nara sumber permasalahan.

c) Dokumentasi

Dokumentasi merupakan catatan peristiwa yang sudah berlalu. Dokumentasi bisa berbentuk tulisan, gambar atau karya-karya monumental dari seseorang (Sugiyono, 2016:329). Dalam penelitian ini dokumen yang digunakan berupa nama lengkap siswa, nilai ulangan tengah ganjil siswa kelas IV SDN 1 Sukodadi. Foto-foto kegiatan penelitian, dan surat izin penelitian juga disertakan sebagai bukti pelaksanaan penelitian.

\section{Teknik Analisis Data}

1. Analisis Data Awal

Uji Normalitas

Uji normalitas adalah pengujian yang bertujuan untuk mengetahui apakah sampel yang kita gunakan berdistribusi normal atau tidak normal. Normal dan tidak normalnya data sampel akan menentukan cara perhitungan statistikanya.

Menurut (Sudjana, 2005:466-467) uji normalitas data yaitu dengan hipotesis

$H_{0}$ : sampel berasal dari populasi yang berdistribusi normal

$H_{a}$ : sampel berasal dari populasi yang berdistribusi tidak normal

Langkah-langkahnya :

1) Hasil pengamatan $x_{1}, x_{2}, x_{3}, \ldots \ldots, x_{n}$ diubah dalam bilangan buku dalam $z_{1}, z_{2}, z_{3}, \ldots, \ldots, z_{n}$ dengan menggunakan rumus :

$$
Z_{1}=\frac{x_{1}-\bar{x}}{s}
$$

Keterangan :

$\bar{x}$ adalah rata-rata dan s adalah simpangan baku sampel

2) Untuk setiap bilangan baku ini dan menggunakan daftar distribusi normal baku, kemudian dihitung peluang $\mathrm{F}\left(Z_{i}\right)=\mathrm{P}\left(\mathrm{z} \leq Z_{i}\right)$, jika nilai $\mathrm{Z}$ negative maka nilai $\mathrm{F}\left(Z_{i}\right)$ adalah $0,5-Z_{\text {tabel }}$ jika nilai $\mathrm{Z}$ positif maka nilai $\mathrm{F}\left(Z_{1}\right)$ adalah $0,5+Z_{\text {tabel }}$

3) Hitung proporsi $z_{1}, z_{2}, z_{3_{z} \ldots} z_{n}$ yang lebih kecil atau sama dengan $z_{i}$

4) Proporsi ini dinyatakan oleh $S\left(z_{i}\right)$

$$
\mathrm{S}\left(Z_{i}\right)=\frac{Z_{1}, Z_{z}, Z_{\text {g max }} Z_{n \text { yang }} \leq Z_{i}}{n}
$$

5) Hitung selisih $\mathrm{F}\left(Z_{i}\right)-\mathrm{S}\left(Z_{i}\right)$ kemudian tetukan harga mutlaknya 
6) Ambil harga terbesar dari harga mutlak tersebut dan harga tersebut adalah $L_{0}$

7) Bandingkan $L_{0}$ dengan nilai krisil L unuk uji liliefors dengan $\alpha=0$,05. Jika $L_{0}<L_{\text {tabel }}$ maka $H_{0}$ diterima artinya data berdistribusi normal (Sudjana, 2005: 467)

Uji Beda (t-test)

Setelah pengumpulan data selesai maka data-data tersebut akan dianalisis dengan uji t. Uji untuk testing signifikan. Adapun rumus yang digunakan adalah sebagai berikut:

$$
\mathrm{t}=\frac{M d}{s \sqrt{\frac{\sum X^{2} d}{N(N-1)}}}
$$

keterangan :

Md : mean dari perbedaan pre test dengan posttest

$\mathrm{xd} \quad$ : deviasi masing-masing subjek (d-Md)

$\Sigma \mathrm{X}^{2} \mathrm{~d} \quad$ : jumlah kuadrat deviasi

$\mathrm{N} \quad$ : subjek pada sampel

d.b : : ditentukan dengan N-1

Hipotesis Uji-t

$\mathrm{H}_{\mathrm{o}} \quad\left(\mu_{1} \leq \mu_{2}\right)$ (Rata-rata nilai posttest tidak lebih atau sama dengan rata-rata nilai pretest)

$\mathrm{H}_{\mathrm{i}} \quad\left(\mu_{1}>\mu_{2}\right)$ (Rata-rata nilai posttest lebih dari rata-rata nilai pretest)

Uji ketuntasan belajar

Untuk mengetahui keefektifan pembelajaran digunakan kriteria ketuntasan belajar sebagai berikut:

1) Ketuntasan Belajar Individu (Perorangan)

Ketuntasan belajar siswa dapat dirumuskan sebagai berikut:

$$
\mathrm{KBI}=\frac{\text { jumlah nilainyang diperolehsiswa }}{\text { jumlah nilai maksimal selurwhnya }} \times 100 \%
$$

(Trianto, 2011: 241)

Apabila siswa telah menguasai sekurang-kurangnya 68\% terhadap materi setiap satuan bahasan yang diajukan.

Ketuntasan individu $\geq 68$ Tuntas, indikator ketuntasan klasikal $\geq 80$ klasikal tuntas.

2) Ketuntasan Belajar Klasikal

Di dalam pengukuran tuntas secara klasikal, dikatakan belajar tuntas dengan rumus:

$$
\mathrm{KBK}=\frac{\text { jumlah siswa yang tuntas belajar }}{\text { jumlah siswa yang mengikuti tes }} \times 100 \%
$$

Indikator ketuntasan klasikal $\geq 80$ klasikal tuntas.

\section{Hasil dan Pembahasan}

Penelitian ini dilaksanakan di SD N 1 Sukodadi khususnya di kelas IV pada tema cita-citaku. Sampel penelitian 32 peserta didik yang mengikuti pembelajaran dengan menerapkan model talking stick. Dari hasil penelitian ini yaitu prngumpulan

datanya menggunakan tes formatif soal pilihan ganda yang terdiri dari 40 soal uji coba dan menjadi 25 soal yang valid untuk soal pretest dan posttest. Rekapitulasi dari Hasil belajar peserta didik dapat disajikan pada tabel 1 sebagai berikut :

Tabel 1. Hasil Pengolahan Nilai Pre-Test dan Post-Test Peserta Didik

\begin{tabular}{lll}
\hline Keterangan & Pretest & Postest \\
\hline Nilai terendah & 40 & 64 \\
Nilai tertinggi & 80 & 100 \\
\hline
\end{tabular}




\begin{tabular}{lllll}
\hline Rata-rata & 63,31 & & \multicolumn{2}{c}{85,50} \\
Uji normalitas & 0,13197 & & 0,14160 & \\
Uji t & 13,3725 & & & \\
\multicolumn{1}{c}{ Uji } & KBI & KBK & \\
ketuntasan & Pretest & postest & Prestest & Postest \\
& $29,79 \%$ & $40,24 \%$ & $50,00 \%$ & $96,88 \%$ \\
\hline
\end{tabular}

Dilihat pada Tabel hasil selisih nilai pretest tertinggi dan terendah berbeda. Nilai tertinggi pretest yaitu 80 ,sedangkan terendah 40 . Nilai rata-rata pretest yaitu 63,31 dan hanya terdapat 16 siswa yang tuntas. Hal tersebut menunjukkan bahwa nilai pada pretest masih rendah dan belum mencapai kriteria ketuntasan minimum (KKM) yaitu 68. Desain yang digunakan dalam penelitian ini adalah Pre Eksperimental Design dengan menggunakan One-Goup pretest-posttest Design. Data dari penelitian ini terdiri dari data pretest dan data posttest pada hasil belajar subtema aku dan cita-citaku. Nilai dari hasil pretest sebagai pengukur kemampuan awal siswa dan nilai hasil posttest diambil dari hasil akhir setelah dilakukan pembelajaran menggunakan model pembelajaran Talking Stick.

Perbandingan antara nilai pretest dan postest yang diperoleh pada akhir pembelajaran dan setelah dilakukan perlakuan model Talking Stick mengalami kenaikan yaitu nilai tertinggi 100 dan terendah 64 dengan nilai rata-rata 85,50 .

Setelah dilakukan analisis data nilai hasil belajar pada nilai pengetahuan diperoleh rata-rata untuk pretest sebesar 63,31 dan postest 85,50 dengan $\mathrm{N}=32$ jadi $\mathrm{db}=\mathrm{N}-1=32-1=31$ yang diperoleh thitung $=$ 13,3725 dengan taraf signifikan $5 \%$ di dapat nilai tabel $=1,6939$. Karena thitung $13,3721>t_{\text {tabel }} 1,6939$ maka $\mathrm{H}_{\mathrm{A}}$ diterima.

Pada hasil perhitungan Uji Ketuntasan pada pretest diperoleh KBI $=29,79 \%$ dan KBK $=50,00 \%$ dengan KKM 68. Sedangkan hasil perhitungan uji ketutasan pada postest diperoleh $\mathrm{KBI}=40,24 \%$ dan KBK= 96,88\% dengan KKM 68. Sehingga dapat disimpulkan bahwa penerapan model Talking Stick efektif terhadap hasil belajar tema cita-citaku siswa kelas IV SDN 1 Sukodadi.

Penelitian ini dilaksanakan pada semester genap tanggal 20 sampai 22 Maret 2019 di SD N 1 Sukodadi Kecamatan Kangkung Kabupaten Kendal tahun pelajaran 2018/2019 pada siswa kelas IV dengan jumlah 32 siswa. Kondisi awal siswa sebelum dilakukan penelitian yaitu rendahnya nilai hasil belajar siswa pada pembelajaran tematik yang sebagian besar masih dibawah kriteria ketuntasan minimal (KKM). Hal ini disebabkan ketika mengajar guru belum menggunakan model pembelajaran yang menyenangkan, siswa belum terlibat aktif dan kreatif di dalam proses pembelajaran sehingga menyebabkan hasil belajarnya rendah. Untuk mengatasi masalah tersebut peneliti memberikan solusi dengan menggunakan model Talking Stick. Oleh karena itu, peneliti mengadakan penelitian dengan judul keefektifan penerapan model Talking Stick terhadap hasil belajar tema cita-citaku siswa kelas IV SD N 1 Sukodadi Kecamatan Kangkung Kabupaten Kendal.

Menurut Sohimin (2014:197) Model pembelajaran Talking Stick termasuk salah satu model pembelajarn kooperatif. Strategi pembelajaran ini dilakukan dengan bantuan tongkat, siapa yang memegang tongkat wajib menjawab pertanyaan dari guru setelah peserta didik mempelajari materi pokoknya. Pembelajaran Talking Stick sangat cocok diterapkan bagi peserta didik SD, SMP, dan SMA/SMK. Selain untuk melatih berbicara, pembelajaran ini akan menciptakan suasana yang menyenangkan dan membuat peserta didik aktif.

Berdasarkan hasil analisis uji coba instrument, dengan mempertimbangkan validitas,reliabilitas, tingkat kesukaran, dan daya pembeda maka dapat didapatkan 25 soal memenuhi kriteria dari 40 soal uji coba instrument. Kemudian 25 yang memenuhi kriteria tersebut digunakan untuk soal pretest dan posttest.

Data awal penelitian menggunakan data dari nilai pretest siswa. Rata-rata nilai pretest yaitu sebesar 63,31. Berdasarkan uji normalitas awal, data awal penelitian yang berasal dari nilai pretest siswa adalah berdistribusi normal. Hal tersebut dibuktikan dengan hasil Lhitung sebesar 0,12759 sedangkan Ltabel 0,15662. Berarti Lhitung 0,12759 < 0,15662 Ltabel. Rata- rata hasil pretest Yang diperoleh masih rendah dikarenakan proses pembelajaran yang berlangsung bersifat monoton. Belum digunakan model pembelajaran sehingga siswa cenderung bosan untuk mengikuti pembelajaran.

Data akhir penelitian menggunakan data dari posttest siswa yaitu untuk mengetahui hasil belajar siswa setelah diberi perlakuan. Berdasarkan uji normalitas, data akhir penelitian dari nilai posttest adalah berdistribusi normal. Hal tersebut dibuktikan dengan Lhitung $0,14160<0,15662$ Ltabel, maka $\mathrm{H}_{0}$ diterima.

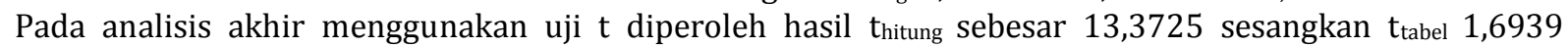
dengan $\mathrm{db}=\mathrm{N}-1=32-1+31$, dan taraf signifikan 0,05. Karena thutng $>$ tabel maka $\mathrm{H}_{0}$ ditolak dan $\mathrm{H}_{\mathrm{A}}$ diterima.

Terkait dengan hasil belajar tematik pada kelas IV menggunakan model Talking Stick yang telah dilakukan oleh peneliti (Wahyuni, Kundera, \& Gagaramusu, n.d.) yang dimuat dalam Jurnal Kreatif 
Tadulako Online Vol. 1 No. 1 tahun 2013 dengan judul "Penerapan Metode Talking Stick untuk Meningkatkan Hasil Belajar IPA Kelas IV di SDN 2 Posona” dan (Mutarto, 2011) yang dimuat dalam jurna Google Cendekia dengan judul "Penerapan Model Pembelajaran Talking Stick Untuk Meningkatkan Pembelajaran IPA Kelas IV SDN 2 Pringapus Kecamatan Dongko Kabupaten Trenggalek". Penggunaan model Talking Stick dalam pembelajaran dapat meningkatkan hasil belajar siswa.Tidak hanya meningkatkan hasil belajar kognitif, namun juga afektif dan motorik. Siswa terlibat aktif berpartisipasi dalam tindakan yang dilaksanakan.

Berdasarkan uraian di atas dapat diketahui bahwa pembelajaran dengan menggunakan model Talking Stick efektif terhadap hasil belajar siswa. Hasil penelitian menunjukkan bahwa penggunaan model Talking Stick juga membantu guru dalam mengelola kelas selama pembelajaran berlangsung.hal ini dikarenakan siswa lebih tertarik, merasa senang dapat mendukung dan membantu keaktifan selama proses pembelajaran.

\section{Simpulan dan Saran}

Berdasarkan rumusan masalah, pengajuan hipotesis, analisis data dan pembahasan, maka peneliti membuat kesimpulan bahwa penerapan model Talking Stick efektif terhadap hasil belajar tema cita-citaku siswa kelas IV SD N 1 Sukodadi. Hal ini dibuktikan dengan diperolehnya nilai pretest dengan rata-rata 63,31 ada 16 siswa yang tuntas dan 16 siswa yang tidak tuntas. Dan hasil posttest dengan rata-rata 85,50 ada 31 siswa yang tuntas dan 1 siswa yang tidak tuntas. Dari perhitungan uji t diperoleh thitung 13,3725 dan ttabel sebesar 1,6939 atau thitung lebih besar dari ttabel yaitu 13,3725 > 1,6939. Maka dapat disimpulkan bahwa penerapan model Talking Stick efektif terhadap hasil belajar tema cita-citaku kelas IV SD N 1 Sukodadi Kecamatan Kangkung Kabupaten Kendal.

Berdasarkan kesimpulan diatas, maka ada beberapa saran yang dipaparkan dari peneliti ini yaitu : 1. Model Talking Stick dapat diterapkan dalam pembelajaran di sekolah untuk meningkatkan hasil belajar siswa. Terutama untuk materi pembelajaran yang luas sebagai solusi untuk memudahkan siswa dalam meringkas dan mengembangkan ide-ide pokoknya, 2. Peran guru sebagai motivator, fasilitator, dan lingkungan pembelajaran yang menyenangkan diperlukan siswa untuk mengoptimalkan belajar mandiri dan mengembangkan pengetahuannya, dan 3. Sebelum menerapkan model pemebelajaran talking stick, guru terlebih dahulu membuat perencanaan pembelajaran yang akan dilaksanakan sesuai dengan sintak model Talking Stick agar pelaksanaan proses pembelajaran akan berlangsung dengan sebagaimana mestinya.

\section{Daftar Rujukan}

Arikunto, S. (2016). Prosedur Penelitian Suatu Pendekatan Praktik. Jakarta: Rineka Cipta.

Djamarah, S. B., \& Zain, A. (2010). Strategi Belajar Mengajar. Rineka Cipta.

Faradita, M. N. (2018). Pengaruh Metode Pembelajaran Type Talking Stick Terhadap Hasil Belajar IPA pada Siswa Kelas 4 Sekolah Dasar. Jurnal Bidang Pendidikan Dasar, 2(1A), 47-58. https://doi.org/10.21067/jbpd.v2i1a.2349

Hakim, Z. R. T. dan Q. A. (2018). Penerapan Model Pembelajaran Cooperative Learning Tipe Talking Stick terhadap Pemahaman Konsep Kegiatan Jual Beli pada Mata Pelajaran IPS Kelas III Sekolah Dasar. Jurnal Pesona Dasar, 6(2), 75-84. Retrieved from http://www.jurnal.unsyiah.ac.id/PEAR/article/download/12199/9467.

Hamalik, O. (2006). Kurikulum dan Pembelajaran. Jakarta: Bumi Aksara.

Majid, A. (2014). Pembelajaran Tematik Terpadu. Bandung: Remaja Rosdakarya.

Mutarto, W. (2011). Penerapan model pembelajaran talking stick untuk meningkatkan pembelajaran IPA kelas IV SDN 2 Pringapus Kecamatan Dongko Kabupaten Trenggalek. Penerapan Model Pembelajaran Talking Stick Untuk ..., 70. Retrieved from http://library.um.ac.id/ptk/index.php?mod=detail\&id=48854

Sadiman, A. S. (2012). Media Pendidikan. Jakarta: PT Raja Grafindo Persada.

Safitri, I. M. M. I. N. (2018). Pengaruh Penerapan Model Talking Stick dengan Bantuan Media Choose Number terhadap Hasil Belajar Biologi di SMP Negeri 3 Sungguminasa Kabupaten Gowa. Jurnal Biotek, 6(1), 131-144. Retrieved from http://journal.uin-alauddin.ac.id/index.php/.

Siregar, S. (2015). Pengaruh Model Pembelajaran Talking Stick terhadap Hasil Belajar dan Aktivitas Visual Siswa pada Konsep Sistem Indra. Jurnal Biotik, 3(2), 100-106. Retrieved from http://jurnal.ar- 
raniry.ac.id/index.php/biotik/article/view/999.

Slameto. (2003). Belajar dan Faktor-faktor yang Mempengaruhinya. Jakarta: PT Rineka Cipta.

Sohimin, A. (2014). 68 Model Pembelajaran Inovatif dalam Kurikulum 2013. Yogyakarta: AR-RUZZ MEDIA. Sudjana. (2005). Metode Statistika. Bandung: Tarsito.

Sugiyono. (2016). Metode Penelitian Kualitatif, Kuantitatif, dan R\&D. Bandung: Alfabeta.

Trianto. (2011a). Desain Pengembangan Pembelajaran Tematik Bagi Anak Usia Dini TK/RA \& Anak Kelas Awal SD/MI. Jakarta: Kencana.

Trianto. (2011b). Model Pembelajaran Terpadu: Konsep, Strategi, dan Implementasinya dalam Kurikulum Tingkat Satuan Pendidikan. Jakarta: Bumi Aksara.

Wahyuni, S., Kundera, I. N., \& Gagaramusu, Y. (n.d.). Jurnal Kreatif Tadulako Online Vol . 1 No . 1 ISSN

2354-614X Penerapan Metode Talking Stick untuk Meningkatkan Hasil Belajar IPA Kelas IV di SDN 2 Posona Jurnal Kreatif Tadulako Online Vol . 1 No . 1 ISSN 2354-614X, 1(1), 64-76. 